\title{
Determining the Knowledge and Attitudes of Nurses about Catheter Associated Urinary Tract Infections
}

\author{
Hilal Türkben Polat ${ }^{1}$ iD , Hakime Aslan² (D)
}

${ }^{1}$ Department of Fundamentals of Nursing, Necmettin Erbakan University, Seydişehir Kamil Akkanat Faculty of Health Sciences, Konya, Turkey

${ }^{2}$ Department of Fundamentals of Nursing, Faculty of Nursing, Inonu University, Malatya, Turkey

\section{Hilal TÜRKBEN POLAT}

Hakime ASLAN

\author{
Correspondence: Hilal Türkben Polat \\ Department of Fundamentals of Nursing, \\ Necmettin Erbakan University, Seydişehir Kamil \\ Akkanat Faculty of Health Sciences, Konya, \\ Turkey \\ Phone:- \\ E-mail: hilaltpolat@hotmail.com
}

\begin{abstract}
Aim: The aim of this study is to evaluate the knowledge and attitudes of nurses about the urinary catheter associated urinary tract infections.

Material method: This research is a descriptive study. The study was conducted between April and May 2021 in a medical faculty hospital. The sample of the study consisted of 220 nurses working in the medical faculty hospital. The data were collected online through an introductory information form and "Catheter Associated Urinary Tract Infections Control Precautions Scale" (CAUTICPS).

Findings: The CAUTICPS mean score of nurses was $64.01 \pm 8.09$ and their knowledge and attitudes were high. It was determined that the difference between the variables of receiving education about infections associated with urinary catheter, knowing about the surveillance rate of the institution and the employed unit and the total mean score of CAUTICPS was statistically significant $(p<0.05)$. It was determined that the knowledge levels of the nurses who received training, knew about the surveillance speed and were employed in the intensive care unit were higher. While there was a positive, weak significant correlation was found between the age and mean scores of CAUTICPS $(p<0.05)$, there was no significant correlation between the duration of employment and total scale score $(p>0.05)$.
\end{abstract}

Conclusion and recommendations: It was determined that the knowledge levels of the nurses about preventing the catheter associated urinary tract infections were high. It is recommended to provide nurses having insufficient knowledge with in-service training. In addition, nurses should play an active role in taking the infection control measures concerning the healthcare of institutions and their surveillance follow-up.

Keywords: Urinary Tract Infections, Urinary Catheterization, CAUTI, Nursing care

\section{Hemşirelerin Kateter Ilişkili Üriner Sistem Enfeksiyonlarına Yönelik Bilgi ve Tutumlarının Belirlenmesi \\ ÖZET}

Amaç: Bu araştırma hemşirelerin üriner kateter ilişkili üriner sistem enfeksiyonlarına yönelik bilgi ve tutumlarının değerlendirilmesi amacıyla yapıımıştır.

Materyal metod: Araşı̧ıma tanımlayıı türdedir. Araştırma bir tıp fakültesi hastanesinde Nisan -Mayıs 2021 tarihleri arasında yürütülmüstür. Araştırmanın örneklemini tıp fakültesi hastanesinde görev yapan 220 hemşire olușturmuştur. Veriler tanıtıı bilgi formu ve "Kateter Ilişkili Üriner Sistem Enfeksiyonları Kontrol Önlemleri Ölçeği (KiÜSEKÖÖ)" ile online olarak toplanmıştır.

Bulgular: Hemşirelerin KiÜSEKÖÖ' den aldıkları ortalama puan $64.01 \pm 8.09$ olup bilgi ve tutumları yüksektir. Üriner kateter ilişkili enfeksiyonlar hakkında eğitim alma durumu, kurumun sürveyans hızını bilme ve çalışılan birim değişkenleri ile KiÜSEKÖÖ toplam puan ortalaması arasındaki farkın istatistiksel açıdan anlamlı olduğu belirlendi $(p<0.05)$. Eğitim alan, sürveyans hızını bilen ve yoğun bakımlarda görev yapan hemşirelerin bilgi seviyelerinin daha yüksek olduğu belirlendi. Yaş ile KiÜSEKÖÖ puan ortalaması arasında pozitif yönde, zayıf düzeyde anlamlı ilişki olduğu belirlenirken $(p<0.05)$, görev süresi ile ölçek toplam puanı arasında anlamlı bir ilişki olmadığı belirlendi ( $p>0.05)$.

Sonuç ve öneriler: Hemşirelerin kateter ilişkili üriner sistem enfeksiyonlarının önlenmesine yönelik bilgi seviyelerinin yüksek olduğu belirlendi. Bilgi yetersizliği olan hemşirelere hizmet içi eğitimlerin verilmesi önerilir. Ayrıca, kurumlarda sağlık bakımı ile ilişkili enfeksiyon kontrol önlemlerinin alınmasında ve surveyans takiplerinde hemşireler aktif rol almalıdır.

Anahtar Kelimeler: Üriner Sistem Enfeksiyonları, Üriner Kateterizasyon, CAUTI, Hemşirelik bakımı 
$\mathbf{H}$ ealthcare-associated infections are the infections that can progress with morbidity and mortality that occur at least 48 hours after admission or within 30 days after discharge, not in incubation period at the patient's admission to the hospital and increase the duration and cost of hospitalization $(1,2)$. Catheter associated urinary tract infections (CAUTI) are among the healthcare-associated infections. CAUTI defined as the findings of urinary tract infections and significant bacteriuria development among patients who had urinary catheters or whose catheters were removed within the last 48 hours $(3,4)$. According to the 2019 national surveillance data of Turkey, the rate of CAUTI varies between 0.2 and 1.8 in the intensive care units CAUTI amount / UC days *1000) (5). The urinary tract infections are $23 \%$ of the infections in the intensive care units and $95 \%$ of these infections are CAUTI (6). Like other healthcare related infections, CAUTIs cause the prolongation of hospital stay, excessive medication, poor patient comfort, increased health costs and loss of nursing labor. (7)

Many factors are effective in the prevention of CAUTI. Complying with the protocols developed concerning urinary catheter care, providing healthcare staff training, making CAUTI surveillance follow-up, removing the urinary catheter when the indications cease and not applying catheterization without indications are the measures to be taken for preventing CAUTI $(8,9,10)$. If there is an indication, it is under the nurses' responsibility upon the doctor request to insert the urinary catheter, provide catheter care, change the drainage bag and make the follow-up (11). For this reason, the effects of nurses' knowledge, attitude and compliance with the infection control measures are major in the prevention of CAUTI.

The studies have reported that nurses do not have sufficient knowledge about the prevention of CAUTI $(12,13)$. Based on the study by Karadağ Arlı, it was revealed that nurses had a high level of knowledge (14). The fact that nurses have high level of knowledge and attitude about CAUTI will lead to a decrease in CAUTI rates, the prevention of infection related mortality and morbidity, an increase in patient satisfaction, and a decrease in hospital expenses. This study was conducted for the purpose of evaluating the knowledge and attitudes of nurses about the prevention of CAUTIs.

\section{METHODS}

Design: The research was a descriptive study.
Place and date of the study: The research was carried out between April and May 2021 in a medical faculty hospital.

Population: The study was conducted in a medical faculty hospital where the urinary catheterization intervention and follow-up frequently takes places. The population of the study consisted of 900 nurses working in the medical faculty hospital.

Sample: Sample of the study consisted of 220 nurses. The sample size was calculated by using the data of a study in which the knowledge and attitudes of nurses working in the intensive care unit about urinary catheterization were evaluated (15). It was determined that the sample should be 194 nurses, with an alpha margin of error of 0.05 , a $95 \%$ confidence interval and an effect size of 0.237 . In this study, using the data obtained from the calculation made according to the attitude score averages, the sample size was determined as 194 nurses, increased by $15 \%$ compared to the literature and completed with 220 nurses (16). The inclusion criteria were determined as follows; working as a nurse in the medical faculty and to be aged between 18 and 60 years. Nurses who are working in the hospital staff but were not actively working because of being on leave or sick leave were not included in the scope of the study.

\section{Data Collection Tools}

Introductory Information Form: It is the form which was prepared by the researcher and includes the socio-demographic characteristics of the participants such as age, gender, and educational background.

Catheter Associated Urinary Tract Infections Control Precautions Scale(CAUTICPS): This scale was developed by Karadağ Arlı and Bakan (17). The scale is a 5-point Likert type and consists of 15 items. While calculating the scale score, the 13th item is scored reversely. High score signifies good knowledge and attitude level. The lowest score to be obtained from the scale is 15 , whereas the highest score is 75. The Cronbach's Alpha value of the scale is 0.83 . Permission was received from the author through email. The Cronbach's Alpha value of the scale is 0.91 in the present study.

Data Collection Method: The online questionnaires were transmitted to nurses through hospital management quality department by email or other social media applications. The first section of the questionnaire includes the statement "I would like to participate in the study" as well 
as participation conditions and purpose and the name of the researchers in order to get the written consent of the participants. The nurses giving the approval in this section participated in the study. Nurses agreeing to participate in the study gave their responses to the introductory information form and Catheter Associated Urinary Tract Infections Control Precautions Scale. The received responses were checked through the system and recorded.

Data Analysis: Number, percentage, mean score, and standard deviation were used to analyze the data. In the comparing knowledge scores with characteristics of nurses, Mann-Whitney-U test was used for non-normally distributed data in comparison of two groups. Kruskal Wallis test was used for non-normally distributed data in comparison of more than two groups. In groups creating significance, Post-hoc tamhane parametric test was used in order to determine which group caused the difference. Spearman's correlation analysis was made in the comparison of several variables and scale total score. The significance level was accepted as $p<0.05$ and in the confidence interval of $95 \%$.
Ethics: Ethics committee approval from Health Sciences Scientific Research Ethics Board of a university (03.02.2021/16) and written permission from the medical faculty hospital were obtained before starting to conduct the study. Permission to use the Catheter Associated Urinary Tract Infections Control Precautions Scale was obtained from the authors.

Limitations of the Research: The limitation of the study is that the study was conducted in a hospital. The results will be related to the nurses working only in the concerning hospital. They cannot be generalized.

\section{RESULTS}

Table 1. Total Mean Scores of the Catheter Associated Urinary Tract Infections Control Precautions Scale of the nurses

\begin{tabular}{l|l} 
Scale total score & $64.01 \pm 8.09$ (Min: 17 Max: 74)
\end{tabular}

Total mean scores of the CAUTICPS scale of the nurses is $64.01 \pm 8.09$ (Min: 17 Max: 74).

Table 2. Total Mean Scores of the Catheter Associated Urinary Tract Infections Control Precautions Scale based on the demographic and professional characteristics of the Nurses

\begin{tabular}{|c|c|c|c|c|c|}
\hline & & $\mathbf{N}$ & $\%$ & $\mathrm{M} \pm \mathrm{SD}$ & $\begin{array}{l}\text { Test Value and } \\
\text { Significance }\end{array}$ \\
\hline \multirow{2}{*}{ Gender } & Female & 182 & 82.7 & $64.19 \pm 8.58$ & \multirow{2}{*}{$\begin{array}{l}U=2721 \\
p=0.380\end{array}$} \\
\hline & Male & 38 & 17.3 & $63.15 \pm 5.14$ & \\
\hline \multirow{4}{*}{ Educational Background } & High School & 39 & 17.7 & $61.64 \pm 9.69$ & \multirow{4}{*}{$\begin{array}{l}K W=7.40 \\
p=0.060\end{array}$} \\
\hline & Associate degree & 35 & 15.9 & $64.57 \pm 4.56$ & \\
\hline & Bachelor's degree & 123 & 55.9 & $64.34 \pm 7.62$ & \\
\hline & Graduate & 23 & 10.5 & $65.43 \pm 11.04$ & \\
\hline \multirow{7}{*}{ Clinic } & Intensive Care ${ }^{a}$ & 46 & 20.9 & $68.15 \pm 3.85$ & \multirow{7}{*}{$\begin{array}{c}\mathrm{KW}=42.59 \\
\mathbf{p}=\mathbf{0 . 0 0 0} \\
\mathbf{a}>\mathbf{c}, \mathbf{d}, \mathbf{g}\end{array}$} \\
\hline & Internal Medicine Clinics ${ }^{b}$ & 47 & 21.4 & $65.25 \pm 8.62$ & \\
\hline & Surgical Clinics ${ }^{c}$ & 38 & 17.3 & $60.81 \pm 11.51$ & \\
\hline & Emergency $^{d}$ & 43 & 19.5 & $60.65 \pm 7.67$ & \\
\hline & Operating Room ${ }^{\mathrm{e}}$ & 22 & 10.0 & $64.90 \pm 5.17$ & \\
\hline & Pediatrics $^{f}$ & 8 & 3.6 & $66.87 \pm 5.69$ & \\
\hline & Other $^{g}$ & 16 & 7.3 & $62.50 \pm 3.94$ & \\
\hline \multirow{2}{*}{$\begin{array}{c}\text { Status of receiving education on } \\
\text { prevention of CAUTIs }\end{array}$} & Yes & 78 & 35.5 & $65.88 \pm 9.21$ & \multirow{2}{*}{$\begin{array}{l}U=3615 \\
\mathbf{p}=\mathbf{0 . 0 0 0}\end{array}$} \\
\hline & No & 142 & 64.5 & $62.99 \pm 7.24$ & \\
\hline \multirow{2}{*}{$\begin{array}{l}\text { Status of knowing the CAUTI } \\
\text { surveillance rate of the institution }\end{array}$} & Yes & 86 & 39.1 & $65.72 \pm 7.51$ & \multirow{2}{*}{$\begin{array}{l}U=4247 \\
p=\mathbf{0 . 0 0 1}\end{array}$} \\
\hline & No & 134 & 60.9 & $62.92 \pm 8.28$ & \\
\hline \multirow{2}{*}{$\begin{array}{c}\text { Status of having a CAUTI related } \\
\text { protocol }\end{array}$} & Available & 138 & 62.7 & $64.39 \pm 8.73$ & \multirow{2}{*}{$\begin{array}{l}U=4863 \\
p=0.081\end{array}$} \\
\hline & N/A & 82 & 37.3 & $63.37 \pm 6.89$ & \\
\hline Average age (years) & \multicolumn{5}{|c|}{$33.03 \pm 9.55(\operatorname{Min}: 20 \quad$ Max 59) } \\
\hline Employment (years) & \multicolumn{5}{|c|}{$12.00 \pm 10.13(\mathrm{Min}: 1$} \\
\hline
\end{tabular}


According to Table 2; $82.7 \%$ of the nurses participating in the research are female, $55.9 \%$ have a bachelor's degree, $35.5 \%$ have received training on CAUTI prevention, $60.9 \%$ of the nurses didn't know the CAUTI surveillance rate of their institution. The average age of the nurses was 33.03 \pm 9.55. Mean employment duration was $12.00 \pm 10.13$ years.

There was a significant difference between nurses status of receiving education on prevention of CAUTIs, in terms of CAUTICPS total scores $(p<0.05)$. The CAUTICPS total scores of nurses knowing the surveillance rate of their institution were significantly high $(p<0.05)$. The CAUTICPS scores of the nurses were significant according to the clinics they worked in $(p=0.000)$. The results of Tamhane post-hoc analysis revealed that there was a significant difference between the nurses working in intensive care unit and those working in surgical ( $p=0.011)$, emergency $(p=0.000)$ and other clinics $(p=0.001)$ in terms of CAUTICPS total scores. Nurses working in the intensive care unit had significantly high scale scores.

Table 3. Correlation between the total mean score of the Catheter Associated Urinary Tract Infections Control Precautions Scale and the Age and Total Duration of Employment

\begin{tabular}{|c|c|c|}
\hline & \multicolumn{2}{|c|}{$\begin{array}{c}\text { Total Mean Score of the Catheter } \\
\text { Associated Urinary Tract Infections } \\
\text { Control Precautions Scale }\end{array}$} \\
\hline & $\mathbf{r}$ & $\mathbf{p}$ \\
\hline Age & 0.171 & 0.012 \\
\hline $\begin{array}{c}\text { Duration of } \\
\text { employment }\end{array}$ & 0.115 & 0.090 \\
\hline r: Spearman Correlation coefficient; $p: 0.05$ significance level \\
\hline
\end{tabular}

There was a positive correlation between CAUTICPS total mean score and age. There was no correlation between the duration of employment and CAUTICPS total scores of the participants.

\section{DISCUSSION}

This study was conducted for the purpose of assessing the knowledge and attitudes of nurses about prevention of CAUTI. It is reported that urinary catheter is inserted to patients treated with CDC admission at the rate of $15-25 \%$. Although urinary catheterization is required for many patients, the justifications related to the indications are not explained for approximately $50 \%$ of the patients (18). More than $60 \%$ of hospital-acquired urinary tract infections are associated with urinary catheter (19). CAUTI can be decreased at the rate of $65-70 \%$ through evidence based standard measures of healthcare professionals (20).
Among the healthcare professionals, nurses in charge of implementing, care and follow-up of the urinary catheterization practice can be a significant transformation agent in decreasing the CAUTI rates (21).

The CAUTICPS total mean score of the nurses participating in the present study was $64.01+8.09$. The knowledge and attitude levels of the nurses on catheter associated urinary tract infections were high. Likewise, Arlı Karadağ 2020 et al., also found that the knowledge levels and attitudes of the nurses were high (14). However, many studies have reported that the knowledge levels of nurses about CAUTI were not at the desired level $(13,22,23)$. Trainings on CAUTI and its prevention should be arranged for nurses within the scope of continuous in-service training programs. The most effective method in the prevention of CAUTI is to decrease the use of catheter and to remove the catheter as earliest as possible (24). It is important for nurses to have up-to-date knowledge in the prevention of CAUTIs and they maintain an effective patient care by using this knowledge in practice (25).

The results of the present study revealed that there was a significant difference between the CAUTICPS total mean score of intensive care nurses and those working in surgical, emergency, and other clinics. Nurses working in the intensive care had significantly high CAUTICPS total mean scores. Intensive care units are risky areas for CAUTI since urinary catheter is applied to more patients in intensive care units, catheter is inserted for a long time, and resistant microorganisms are mostly isolated. In this sense, intensive care unit nurses have important responsibilities. Urinary tract infections constitute $23 \%$ of the infections in the intensive care unit and it is reported that approximately $95 \%$ of the urinary tract infections in the intensive care units are associated with catheter (6)

The results of the present study indicated that the knowledge and attitudes of nurses receiving education on CAUTI were significantly higher than those who did not. It was reported that the knowledge and attitudes of the nurses trained on infection control measures were high (14) and following the education, the CAUTI rates declined significantly (26). The training, attitudes, and inspections of nurses are important as required by the role of being a primary caregiver in the prevention of CAUTI. The principle suggestions for CAUTI prevention include inserting the catheter only when there is an indication and assessing its necessity, using it for a necessary duration, inserting it by trained persons through complying 
with aseptic techniques, lack of interruption of urine flow, implementation of hand hygiene and the application of standard measures. In addition to these suggestions, training the healthcare professionals about catheter care and removing the catheter as earliest as possible are among the common suggestions by the guidelines published by professional organizations $(8,25,27)$.

Results of the present study indicated that there was a significant difference between knowledge and attitudes of the nurses knowing the surveillance rate of their institution and those who did not. In Turkey, the healthcare associated infection rates are reported through the data coming from the hospitals via national healthcare services related infection surveillance system. The CAUTI rate of each hospital is stated in this report. The required regulatory activities are planned and implemented based on these infection rates and healthcare related infection rates are tried to be decreased.

According to results of the present study, as age of the participants increased, their knowledge and attitudes about the prevention of CAUTIs increased. In the study carried out by Aylaz et al., (2015) for determining the knowledge levels of nurses on hospital infections, they found that older nurses had higher knowledge scores than those who were younger (28). It is considered that with increasing age nurses have an increase in their knowledge and attitudes as a result of the increase in their professional knowledge, skills and experiences. According to results of the present study, there was no significant correlation between the duration of employment and the scale total scores. The average duration of employment of the nurses participating in the present study was $12.00 \pm 10.13$ years. In contrast to the present study, there are studies indicating that as the nurses' duration of working in the profession increased, their level of knowledge on healthcare related infections increased (29).

\section{CONCLUSION}

Nurses are healthcare team members having the most frequent communication with individual patients in charge of interventions such as applying the urinary catheter on the individual, its follow-up and drainage, which is why they have significant roles in decreasing CAUTIs. According to results of the present study, the knowledge and attitudes of nurses about CAUTIs were high. The knowledge and attitudes of intensive care nurses about CAUTIs were significantly high. The knowledge and attitudes increase with the increasing age. The scale scores of the nurses receiving education on CAUTIs and knowing the CAUTI surveillance rate of their institution were significantly high. Based on these results, it is recommended that;

- The nurses be provided with continuous in-service training about prevention of CAUTIs in line with the up-to-date guidelines

- Nurses should conduct scientific studies on CAUTIs

- Studies be planned with more participants and with other health professions.

\section{DECLARATIONS}

Funding: This research did not receive any specific grant from funding agencies in the public, commercial, or notfor-profit sectors.

Conflict of interests: The authors declare that there is no personal or financial conflict of interest within the scope of the study.

Ethical Approval: Health Sciences Scientific Research Ethics Board of a university (03.02.2021/16)

Author Contribution: Research idea: HTP, HA, Research design and data collection: HTP, HA, analysis and writing article: HTP, HA.

\section{REFERENCES}

1. Haque M, Sartelli M, McKimm J, Abu Bakar M. Health care-associated infections-an overview. Infect Drug Resist. 2018;11:2321- 33.

2. Trubiano JA, Padiglione AA. Nosocomial infections in the intensive care unit. Anaesthesia \& Intensive Care Medicine. 2015;16(12):598-602.

3. Yenilmez, E., Ülçay, A., Görenek, L., Diktaş, H. Yoğun bakım ünitelerinde gelişen sağlık bakımı ile ilişkili enfeksiyonların güncel tanımları. J Clin Anal Med, 2015; 6: 401-404

4. Ulusal Sağlık Hizmeti İlişkili Enfeksiyonlar Sürveyans Rehberi Ankara 2017 uzman matbaacılık https://hsgm.saglik.gov.tr/depo/birimler/ Bulasici-hastaliklar-db/hastaliklar/SHIE/Klavuzlar/Ulusal Saglik Hizmeti_lliskili_Enfeksiyonlar_Surveyans_Rehberi_Versiyon_1.pdf

5. Halk Sağlığı Genel Müdürlüğü (HSGM). (2019).Ulusal sağlık hizmeti ilişkili enfeksiyonlar sürveyans rehberi 2019, Erişim 02.05.2021 https://hsgm.saglik.gov.tr/depo/birimler/Bulasici-hastaliklar-db/ hastaliklar/SHIE/Raporlar/USHESA_Ozet_Raporu_2019.pdf

6. Shuman, E. K., \& Chenoweth, C. E. Urinary Catheter-Associated Infections. Infectious disease clinics of North America, 2018; 32(4), 885-897. https://doi.org/10.1016/j.idc.2018.07.002

7. Özbaş A, Seyhan Ak E. Ortopedi hastalarında üriner sistem enfeksiyonları. Turkiye Klinikleri, J Surg Nurs-Special Topics. 2017;3(1):23-31. 
8. Association for Professionals in Infection Control and Epidemiology (APIC). (2015). Guide to Preventing Catheter-Associated Urinary Tract Infections, Erişim 15.11.2018, http://apic.org/Resource_/ EliminationGuideForm/0ff6ae59-0a3a-4640-97b5-eee38b8bed5b/ File/CAUTI_06.pdf.

9. European Centers for Disease Control and Prevention (ECDC). (2018). Guideline for Prevention of Catheter-Associated Urinary Tract Infections, Erişim 15.05.2021, https://ecdc.europa.eu/en/ publications-data/directory-guidance-prevention-and-control/ healthcare-associated-infections

10. Andrade V.L.F., Fernandes F.A.V. Prevention of catheter-associated urinary tract infection: implementation strategies of international guidelines. Revista Latino-Americana De Enfermagem; 2016; 24:e2678

11. Hemşirelik Yönetmeliğinde Değişiklik Yapılmasına Dair Yönetmelik https://www.thder.org.tr/list/yonetmelik?page=2 e.t 05.05.2021

12. Shehab MS. Impact of Protocol of Care of Patients Undergoing Urinary Catheterization on Nurses' Knowledge. International Journal of Caring Sciences. 2017;10(2):1013-20.

13. Chenoweth, C.E., Gould, C.V., \& Saint, S. Diagnosis, management, and prevention of catheter-associated urinary tract infections. Infectious Disease Clinics, 2014; 28(1), 105-119.

14. Karadağ Arlı Ş, Bakan A.B. Kateter İlişkili Üriner Sistem Enfeksiyonları Kontrol Önlemlerine Yönelik Hemşirelerin Bilgi ve Tutumlarının Değerlendirilmesi. Hacettepe Üniversitesi Hemşirelik Fakültesi Dergisi 2020; 7(1): 1-7. DOI: 10.31125/hunhemsire.715021

15. Shaver, B., Eyerly-Webb, S. A., Gibney, Z., Silverman, L., Pineda, C., \& Solomon, R. J. (2018). Trauma and Intensive Care Nursing Knowledge and Attitude of Foley Catheter Insertion and Maintenance. J Trauma Nurs, 2018; 25(1), 66-72. https://doi.org/10.1097/ JTN.0000000000000344

16. Yıldırım Kaptanoğlu, A. (2013). Sağlık Alanında Hipotezden Teze. Beşir Kitabevi. İstanbul.

17. Arli SK, Bakan AB. Development of the Catheter- Associated Urinary Tract Infections Control Precautions Scale. J Contin Educ Nurs. 2018; 49(11):507-13.

18. Oman $\mathrm{K}$, Makic $\mathrm{M}$, Fink $\mathrm{R}$, et al. Nurse-directed interventions to reduce catheter-associated urinary tract infections. Am J Inf Control. 2012;40(6):548-553

19. Gong $Y$, Zhao L, Wang $L$, Wang $F$ : The effect of clamping the indwelling urinary catheter before removal in cervical cancer patients after radical hysterectomy. J Clin Nurs 2017; 26: 1131-6.

20. Umscheid CA, Mitchell MD, Doshi JA, Agarwal R, Williams K, Brennan PJ. Estimating the proportion of healthcare-associated infections that are reasonably preventable and the related mortality and costs. infection control and hospital epidemiology 2011; 32(2): 101-114.

21. Tyson, A. F., Campbell, E. F., Spangler, L. R., Ross, S. W., Reinke, C. E., Passaretti, C. L., \& Sing, R. F. (2020). Implementation of a NurseDriven Protocol for Catheter Removal to Decrease CatheterAssociated Urinary Tract Infection Rate in a Surgical Trauma ICU. Journal of intensive care medicine, 35(8), 738-744. https://doi. org/10.1177/0885066618781304

22. Seyhan Ak, E. \& Özbaş, A. (2018). The effect of education of nurses on preventing catheter associated urinary tract infections in patients who undergo hip fracture surgery. Journal of Clinical Nursing, 27(56), 1078-1088.

23. Jain, M., Dogra, V., Mishra, B., et al. (2015). Knowledge and attitude of doctors and nurses regarding indication for catheterization and prevention of catheter-associated urinary tract infection in a tertiary care hospital. Indian Journal of Critical Care Medicine: peer-reviewed, official publication of Indian Society of Critical Care Medicine. 19(2), 76
24. Meddings J, Rogers M, Krein S, Fakih M, Olmsted R, Saint S. Reducing unnecessary urinary catheter use and other strategies to prevent catheter-associated urinary tract infection: an integrative review. BMJ Qual Saf. 2014;23(4):277-289.

25. Centers for Disease Control and Prevention. Catheter-associated urinary tract infec-tions (CAUTI). Available from:https://www.cdc. gov/hai/ca_uti/uti.html. Access date:15.05.2021

26. Gordon, Pamela R., "The Effects of Nursing Education on Decreasing Catheter Associated Urinary Tract Infection Rates" (2015). Walden Dissertations and Doctoral Studies. 583.

27. Lo, E., Nicolle, L.E., Coffin, S.E., et al. (2014). Strategies to prevent catheter-associated urinary tract infections in acute care hospitals: 2014 update. Infection Control \& Hospital Epidemiology, 35(2), 32-47.

28. Aylaz, R., Şahin, F., Yıldıım, H. Hemşirelerin hastane enfeksiyonu konusuna ilişkin bilgi düzeylerinin belirlenmesi. Balikesir Sağlık Bilimleri Dergisi, 2018; 7 (2): 67-73.

29. Asadollahi, M., Bostanabad, M.A., Jebraili, M., et al., Nurses'knowledge regarding hand hygiene and its individual and organizational predictors. Journal Of Caring Sciences, 2015; 4: 45-53. 